Division Of Agriculiural Sciences

\title{
Production of \\ GRASS SEED \\ in CALIFORNIA
}

D. C. SUMNER JOHN R. GOSS VERN L. MARBLE

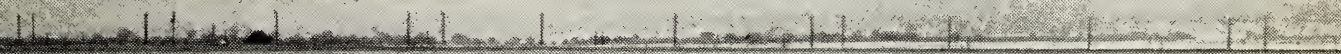

CALIFORNIA AGRICULTURAL

Experiment Station

Extension Service

CIRCULAR 487 


\section{Should YOU grow grass seed?}

Here is a general, rather than a detailed discussion of grass seed production. More specific information on species and varieties may be obtained from your University of California Farm Advisor or from the Department of Agronomy at Davis.

This circular will tell you what it takes to raise grass seed commercially and perhaps help you determine whether you can do it successfully.

\section{Briefly-growing grass seed has:}

\section{ADVANTAGES ...}

Except for harvesting problems with some grasses, production is not difficult.

Given favorable climate, high yields, inexpensive water, and low production costs, you can make a profit on moderate acreage.

Grass seed production fits well into a rotation system-the crop tends to improve the soil on which it is grown.

You can usually expect additional income from the by-product-feed.

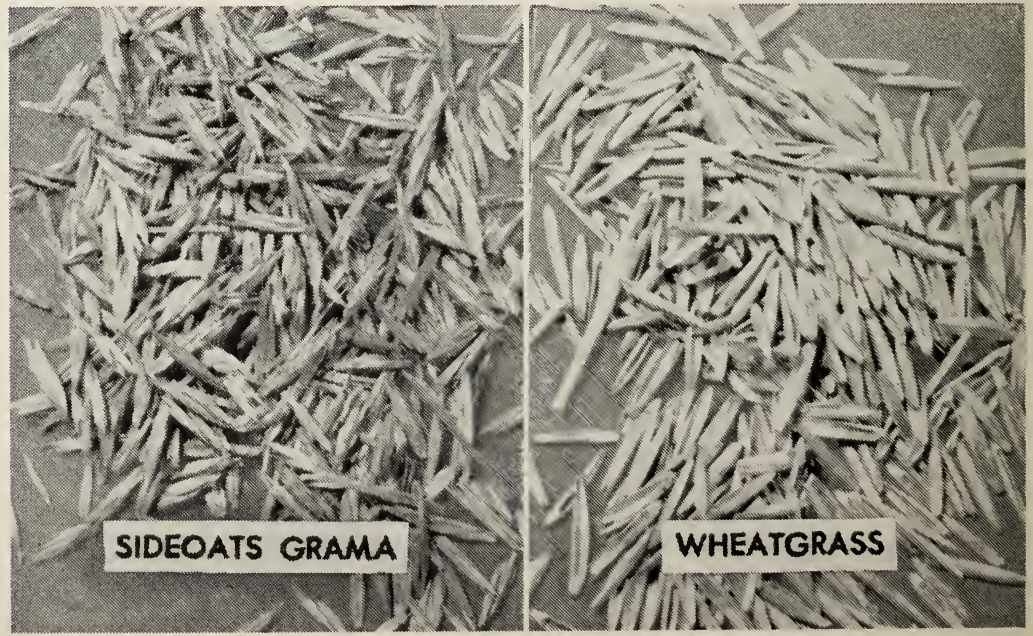



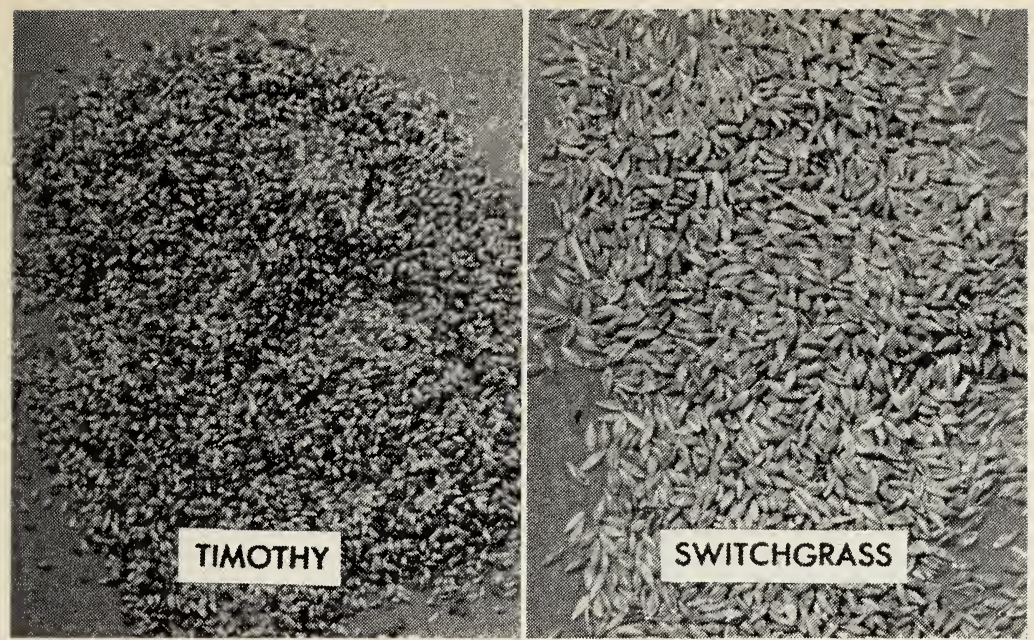

\section{and DISADVANTAGES}

The crop requires considerable special attention. The grower should be experienced in row crops, irrigation, and seed production.

You cannot just think a field is free from weeds, mixtures, and off-typesyou must know it is.

Prices offered for grass seed are more sensitive to supply and demand than most other crops, and supply and demand are greatly affected by the vagaries of climate.

You must be observant, willing to experiment, and able to adjust recommended cultural practices to your own farming conditions.

\section{THE AUTHORS:}

Dorman C. Sumner is Lecturer in Agronomy and Associate Specialist in the Department of Agronomy, Davis. John R. Goss is Lecturer and Assistant Agricultural Engineer in the Experiment Station, Davis. Vern L. Marble is Associate Agriculturist in the Agricultural Extension Service, Davis. 


\section{THE ECONOMICS}

\section{It's a high-income crop but success \\ is dependent on uncontrollable factors}

It is inadvisable to set up new farming projects based solely on grass seed production. Established and diversified row and grain crop enterprises might well consider grass seed production as a profitable addition to their rotation systems.

Only on rare occasions has short-term -or "in and out"- - grass seed production been profitable. In addition, in areas of high land values and competition with cash crops of higher return, yields may have to be exceptionally high for profitable operation.

\section{Demand and supply}

Generally speaking, grass species with wide adaptation and strong demand are

This discussion of adaptation of grasses as seed crops to various areas of the state, and responses to cultural treatments is admittedly incomplete for several reasons:

In a publication of this scope it is not possible to cover all of the problems that may arise during the growing of a great many varieties and species of grass. A far larger book would be needed.

Grass seed production in California is in most cases relatively new and it iakes years of experience to accumulate information on adaptations and yields in various climates-information that has been gathered for other crops grown in the state.

New varieties of grass, new insecticides, new methods of controlling weeds and diseases are being developed every day and detailed information on them is sometimes obsolete before it is printed.

So when we say a grower must learn some practices by experience we mean just that. What works for him may not work for his neighbor. extensively produced as seed crops. Some are already in oversupply, but supplies and grower prices do fluctuate, giving reasonable returns in most years. The seed supply of the more popular, easily produced, summer-growing grasses usually keeps up with the much smaller demand in good crop years. Production varies considerably, depending on the weather in the area of use. In years of good growing conditions and an excess of pasture feed, a portion of the pastures and hay fields in the area of major use are left to mature a seed crop instead of being pastured. This complicates supply and selling price for the producer of seeds of common strains.

Many strains exhibiting greater disease resistance, better feed qualities, and higher yields have been, and are being developed. It is believed that such strains present the potential California seed grower with the greatest opportunity. It must be remembered that the demand for these improved strains is still comparatively small. Volume of future use will depend largely on the retail price of the seed. It is well established that many good grasses are not being used because the seed costs too much.

\section{Cost of production}

The costs of producing a grass seed crop vary with soil, climate, weed problems, water, and labor. It is not possible to give representative figures, but peracre costs should be similar to those for producing alfalfa seed in the same area.

\section{Processing and cleaning}

Seeds of some grasses, especially among the warm-weather grasses, have appendages and/or hairs that cause the 
seeds to cling to each other and to the straw, when being threshed or cleaned. These appendages and hairs must be removed, to simplify cleaning, handling, and marketing.

\section{Marketing}

Seed companies and cooperatives have well-organized marketing arrangements throughout the areas of major grass seed use. They are also in touch with changing supply and demand. Farmers interested in growing grass seed crops are advised to plan and work with a seed company or cooperative in selecting the species to be grown and marketing of the crop.

The table on page 8 lists the currently recognized strains of grasses released and recommended by the experiment stations in the areas of major use. It is difficult to prepare an up-to-date list because government agencies and state experiment stations are constantly working to improve the performance of grasses.

Predicting yields for any area of the state or for any farm is a highly speculative matter because of the wide variations in soil, climate, available water, and grower skill. In addition the seedproduction capabilities of some strains within a species may appear to be low because of inadequate testing, but could respond favorably to different climatic conditions.

\section{Other income}

The straw produced by a seed crop is a valuable stock roughage when properly handled to preserve the properties of good hay. In some areas it is especially valued as feed for horses.

Pasturing seed fields for additional income has distinct disadvantages. In the older seed-producing areas of the U.S., where much of the seed is produced in solid stands, fields are often used as pastures in the fall, or spring, or both. Under such treatment the stands are weakened by trampling, heavy grazing, and the introduction of weeds. Seed yields and quality are consequently lowered, and the seed crop rapidly becomes incidental to pasturage.

\section{Grasses improve soil}

Grass seed crops are noted for returning large amounts of organic matter to the soil. Their extensive fibrous root system opens the soil below normal plow depth, and partial renewal of the root system each year adds organic matter. Also, the cultivation necessary to control weeds leaves the land in much better condition for other crops.

\section{THE TYPES OF GRASSES}

\section{Some do better in cooler climates; some require warmer temperatures}

With few exceptions, all economic grasses are used either for turf or for livestock feed-as irrigated or dryland pasture, hay, silage, or range. These grasses can be divided into two groups, according to season of growth.

\section{Winter, or cool-season, grasses}

This group contains by far the larger number of grass species of economic im- portance. Most important in this group, because of the greater volumes of seed required, are tall fescue; orchardgrass; smooth brome; timothy; crested, tall, intermediate, and pubescent wheatgrass; Merion and Kentucky bluegrass; the several strains of bentgrass; the lawn or turf types of fescues, such as red and sheep fescue; and the annual and perennial ryegrasses. Also important-but on 
a smaller acreage-are hardinggrass, mountain brome, prairie brome, veldtgrass, tall oatgrass, and blando brome.

Grasses in this group grow more vigorously during the fall, spring, and early summer than during the heat of summer. They characteristically begin developing or maturing a seed crop as the days become longer in the spring.

Seed production capabilities of these grasses are affected by winter temperatures and day length, though there is considerable variation in response between and within species. Some, like bluegrass, have rather exacting winter temperature requirements that few areas in California can meet. The winter optimum temperature requirements for most of these grasses are not precisely known. However, it is quite probable that bluegrass, timothy, smooth brome, bentgrass, red and sheep fescues, wheatgrass, and orchardgrass have rather exacting temperature requirements for high seed yield. The latter ones are perhaps less sensitive. There may also be considerable variation in tolerance to high daytime temperatures in the early summer during flowering and seed development.

\section{Summer, or warm-weather, grasses}

Very few warm-or hot-weather species have a seed market volume approach. ing that enjoyed by most cool-weather species because they are used only in localized areas. Examples of the more important summer-growing grasses are rhodesgrass, dallisgrass, sideoats grama, sand lovegrass, weeping lovegrass, switchgrass, bluestems, and blue panic.

There is a considerable variation in cold tolerance among and within species of these summer-growing grasses. For example, most varieties of rhodesgrass seldom withstand winter temperatures

Experimental fields of grass seed varieties at Davis. Left to right, sideoats grama, switchgrass, and sand lovegrass. at Davis, California; other grasses go completely dormant with new basal growth emerging from the crown area in early spring; still others, like the lovegrasses, exhibit a considerable amount of green, but dormant, vegetation throughout the winter.

The greater part of the vegetative growth of warm-weather grasses takes place during the summer months. Seed is produced in mid-summer or September or October, depending on the species. Sideoats grama, weeping lovegrass, blue panic, rhodesgrass, and dallisgrass normally produce a seed crop in June or July. If growing conditions are ideal and long, they can produce a second crop. The second crop, maturing in September or October, may be profitable if flowering and seed development have not been damaged by too high temperatures. Sand lovegrass and switchgrass produce but one seed crop which matures in late September.

Although this group of grasses requires the hot summer weather, seed yields are often reduced if temperatures are unusually high at flowering.
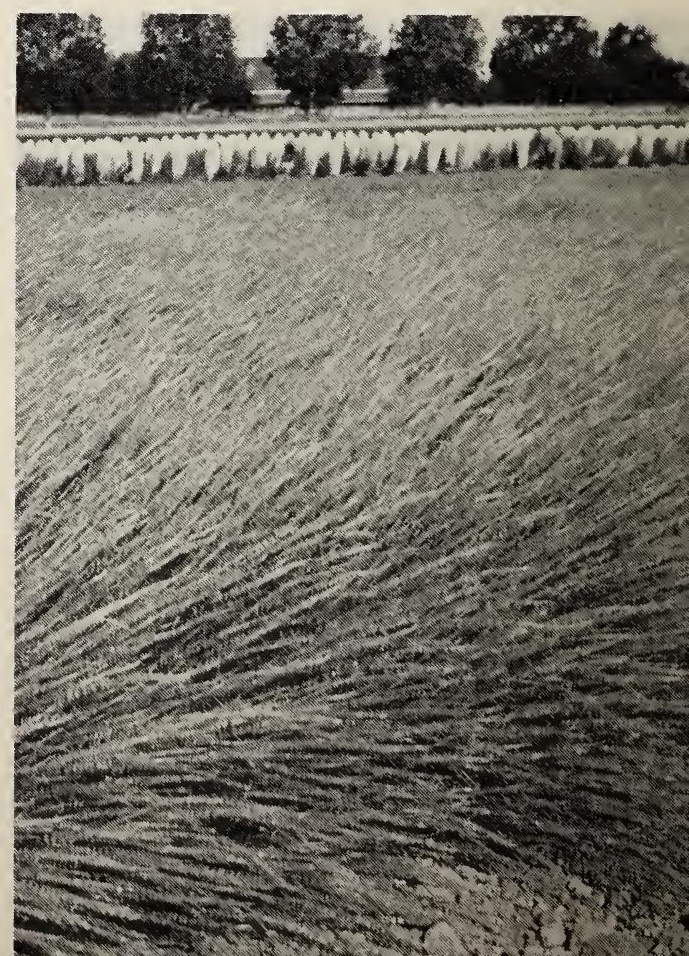


\section{THE PRODUCTION AREAS ...}

\section{extend from cool, mountain valleys}

\section{to the warmer coastal plains}

\section{Mountain valleys of intermediate elevation}

Generally speaking, the cool-season grasses can be expected to produce highest seed yields under the cooler fall and spring temperatures in mountain valleys at intermediate elevations (usually above 2000 and below 5000 feet). Species requiring more exacting winter temperatures for maximum seed production, do better at the higher elevations. However, at these elevations, late spring frosts can greatly reduce seed yields.

\section{Central Valley}

Warm-weather grasses should do well as seed crops in the Central Valley. Much of this area is at or near the minimum requirements of the more exacting species that need low winter temperatures. Their economic production in the Central Valley is questionable in most years.
Other cool-weather grasses can produce reasonable yields. However, the relative shortness of the cool period in the spring may prevent maximum yield of some species. (See table, page 8.)

\section{Coastal valleys}

Some of the cool-weather grasses demanding less critical winter temperatures may be adapted to the coastal areas.

The warmer coastal areas-in Ventura and Santa Barbara counties, for example -may, with adequate irrigation, produce profitable seed crops of summer grasses. The summer weather, however, must be warm enough to mature the seed crops. Foggy coastal areas of prolonged high humidities and low light intensities may not mature a seed crop of the summer grasses, and plant diseases (like rust and mildew) may prevent economical production of most grasses.

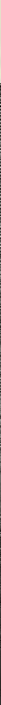




\begin{tabular}{|c|c|c|c|c|c|}
\hline Cropa & Area of major use & Market ${ }^{b}$ & $\begin{array}{l}\text { Yields } \\
\text { generally } \\
\text { expected } \\
\text { lbs./acre }\end{array}$ & $\begin{array}{l}\text { California } \\
\text { areas best } \\
\text { suited for } \\
\text { production }\end{array}$ & $\begin{array}{l}\text { Suggested } \\
\text { seeding } \\
\text { rates } \\
\text { lbs./acre }\end{array}$ \\
\hline $\begin{array}{l}\text { Bentgrass } \\
\begin{array}{l}\text { (Agrostis spp.) } \\
\text { Astoria*.... } \\
\text { Highland*... }\end{array}\end{array}$ & $\begin{array}{l}\text { U.S. } \\
\text { U.S. }\end{array}$ & $\begin{array}{l}\mathrm{E} \\
\mathrm{E}\end{array}$ & $\begin{array}{l}200 \\
200\end{array}$ & $\begin{array}{l}\text { I M } \\
\text { I M }\end{array}$ & $\begin{array}{l}2 \\
2\end{array}$ \\
\hline $\begin{array}{l}\text { Bromegrass, Smooth } \\
\text { (Bromus inermus) }\end{array}$ & & & & & \\
\hline $\begin{array}{l}\text { Achenback }{ }^{*} \ldots \\
\text { Elsberry . . . . . } \\
\text { Fisher }\end{array}$ & $\begin{array}{l}\text { Kans. } \\
\text { Ia.-Mo. } \\
\text { Ia. }\end{array}$ & $\begin{array}{l}\mathrm{L} \\
\mathrm{L} \\
\mathrm{L}\end{array}$ & $\begin{array}{c}* 450 \\
? \\
?\end{array}$ & $\begin{array}{l}\text { I M } \\
\text { I M } \\
\text { I M }\end{array}$ & $\begin{array}{l}4-6 \\
4-6 \\
4-6\end{array}$ \\
\hline $\begin{array}{l}\text { Lancaster* } \\
\text { Lyon*...... } \\
\text { Manchar* }\end{array}$ & $\begin{array}{l}\text { Nebr. } \\
\text { Nebr. } \\
\text { Ida. }\end{array}$ & $\begin{array}{l}\mathrm{L} \\
\mathrm{L} \\
\mathrm{L}\end{array}$ & $\begin{array}{c}? \\
? \\
* 350\end{array}$ & $\begin{array}{l}\text { I M } \\
\text { I M } \\
\text { I M }\end{array}$ & $\begin{array}{l}4-6 \\
4-6 \\
4-6\end{array}$ \\
\hline $\begin{array}{l}\text { Saratoga* } \\
\text { Southland* } \\
\text { Commercial }\end{array}$ & $\begin{array}{l}\text { N.Y. } \\
\text { Okla. }\end{array}$ & $\begin{array}{l}\mathrm{L} \\
\mathrm{L} \\
\mathrm{E}\end{array}$ & $\begin{array}{c}* 400 \\
* 500 \\
?\end{array}$ & $\begin{array}{l}\text { I M } \\
\text { I M } \\
\text { I M }\end{array}$ & $\begin{array}{l}4-6 \\
4-6 \\
4-6\end{array}$ \\
\hline $\begin{array}{l}\text { Bluegrass } \\
\begin{array}{l}\text { (Poa pratensis) } \\
\text { Merion*...... } \\
\text { Kentucky . . . } \\
\text { Delta....... }\end{array}\end{array}$ & $\begin{array}{l}\text { U.S. } \\
\text { U.S. } \\
\text { U.S. }\end{array}$ & $\begin{array}{l}\mathrm{E} \\
\mathrm{E} \\
\mathrm{L}\end{array}$ & $\begin{array}{l}200-800 \\
200-800 \\
200-800\end{array}$ & $\begin{array}{l}\text { I M } \\
\text { I M } \\
\text { I M }\end{array}$ & $\begin{array}{l}1-2 \\
1-2 \\
1-2\end{array}$ \\
\hline $\begin{array}{l}\text { Arboretum . . . } \\
\text { Newport . . . }\end{array}$ & $\begin{array}{l}\text { U.S. } \\
\text { U.S. }\end{array}$ & $\begin{array}{l}\mathrm{L} \\
\mathrm{L}\end{array}$ & $\begin{array}{l}200-800 \\
200-800\end{array}$ & $\begin{array}{l}\text { I M } \\
\text { I M }\end{array}$ & $\begin{array}{l}1-2 \\
1-2\end{array}$ \\
\hline $\begin{array}{l}\text { Fescue, Tall } \\
\begin{array}{r}\text { (Festuca arundinacea }) \\
\text { Alta }^{*} \ldots \ldots \ldots \\
\text { Kentucky } 31^{*} \ldots \ldots \\
\text { Goars }{ }^{*} \ldots \ldots\end{array}\end{array}$ & $\begin{array}{l}\text { U.S. } \\
\text { S.E. U.S. } \\
\text { Calif. }\end{array}$ & $\begin{array}{l}\mathrm{E} \\
\mathrm{E} \\
\mathrm{L}\end{array}$ & $\begin{array}{l}{ }^{*} 600-900 \\
{ }^{*} 600-900 \\
{ }^{*} 600-900\end{array}$ & $\begin{array}{l}\text { I M-C V } \\
\text { I M-C V } \\
\text { I M-C V }\end{array}$ & $\begin{array}{l}2-3 \\
2-3 \\
2-3\end{array}$ \\
\hline $\begin{array}{l}\text { Fescue, Red } \\
\begin{array}{l}(F \text {. rubera }) \\
\text { Illahee* ... . . . . . . . . . . . . } \\
\text { Rainier* . } \\
\text { Pennlawn* . . } \\
\text { Creeping Red Fescue }\end{array}\end{array}$ & $\begin{array}{l}\text { U.S. } \\
\text { U.S. } \\
\text { U.S. } \\
\text { U.S. }\end{array}$ & $\begin{array}{l}\text { E } \\
\text { E } \\
\text { L } \\
\text { E }\end{array}$ & $\begin{array}{c}300 \\
300 \\
? \\
300\end{array}$ & $\begin{array}{l}\text { I M } \\
\text { I M } \\
\text { I M } \\
\text { I M }\end{array}$ & $\begin{array}{l}2-4 \\
2-4 \\
2-4 \\
2-4\end{array}$ \\
\hline $\begin{array}{l}(F . \text { comutata }) \\
\text { Chewings Fescue. }\end{array}$ & U.S. & $\mathrm{E}$ & 300 & I M & $2-4$ \\
\hline
\end{tabular}

a Asterisk after species' name indicates that foundation or certified seed is available.

b $\mathbf{E}=$ extensive; $\mathrm{L}=$ limited.

c Asterisk before yield figure indicates the seed production at Davis, California, from small plots.

d I $\mathrm{M}=$ Intermediate mountain elevation; $\mathrm{C} \mathrm{V}=$ Central Valley. 


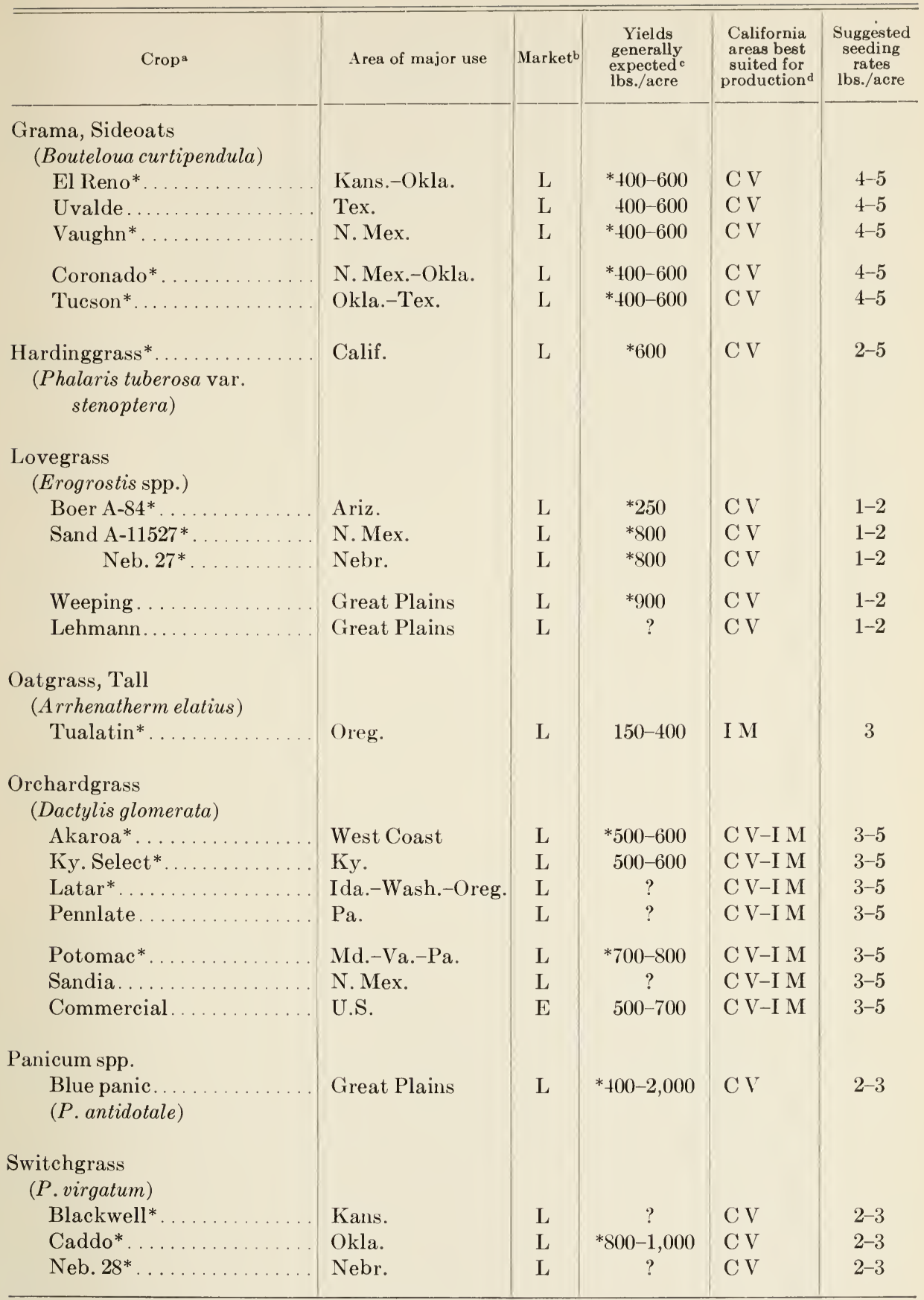

a Asterisk after species' name indicates that foundation or certified seed is available.

b $\mathrm{E}=$ extensive; $\mathrm{L}=$ limited.

c Asterisk before yield figure indicates the seed production at Davis, California, from small plots.

d I M = Intermediate mountain elevation; C V = Central Valley. 


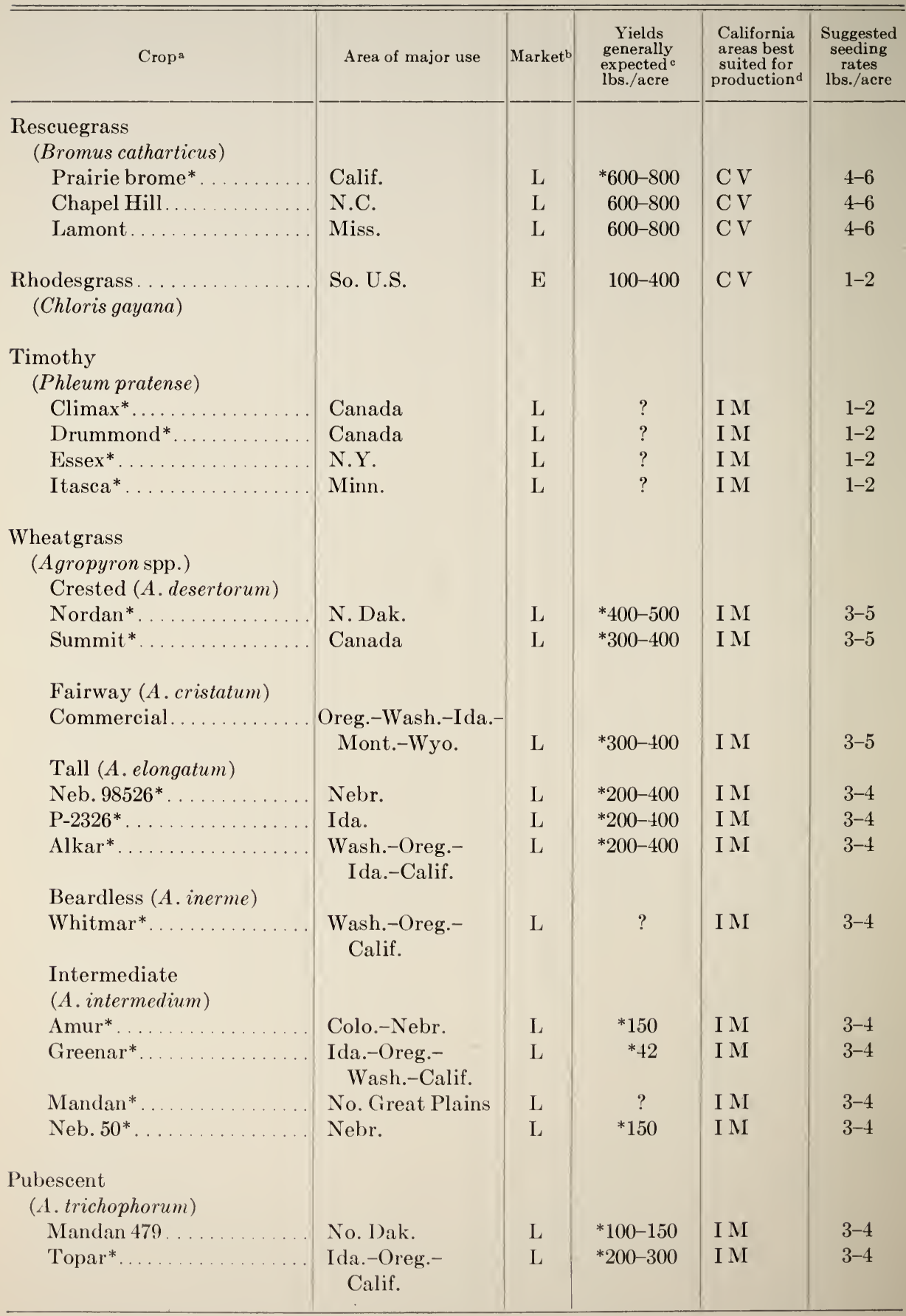

a Asterisk after species' name indicates that foundation or certified seed is available.

b $\mathrm{E}=$ extensive; $\mathrm{L}=$ limited.

- Asterisk before yield figure indicates the seed production at Davis, California, from small plots.

d I $\mathrm{M}=$ Intermediate mountain elevation. $\mathrm{C} \mathrm{V}=$ Central Valley. 


\section{CULTURAL PRACTICES . .}

\section{have to be learned by individual growers; experience is probably the best teacher}

\section{Seedbed preparation}

Stands will be most productive on the better soils. Land selected for grass seed production should be as free as possible from weeds. Seedling perennial grasses grow slowly and weeds can soon weaken a good stand of young grass. In general, soils should be loamy, friable, and easily worked. A fine, firm seedbed, as used for alfalfa seed production, will help keep the seeds from being placed too deep, and assure firm contact with the soil.

For fall seeding, the land should be spring-plowed and summer-fallowed; cultivate if necessary to prevent weeds from setting seed. Spring seeding should be on land fallowed the previous year, plowed early, and worked into a fine, firm, weed-free condition. Before seeding, the land should be harrowed lightly to eliminate all germinating weed seeds.

Good seedbed preparation reduces weed problems. In some circumstances it may be advisable to irrigate weeds up after the seedbed is prepared and spray them out with a fortified oil spray before seeding.

\section{What to plant}

Seed is the least expensive item in production costs. Use only the best.

When possible, produce certified seed. It will be more readily accepted in the out-of-state market.

Most seed is grown for out-of-state use and the California grower competes in the market with the local growers. Every advantage should be taken to turn out the best possible product, and establish a reputation for quality seed. When available, the foundation or registered seed planted should be from the area of use. This will ensure the grower and the ultimate consumer that the seed produced is the recognized and recommended variety. Foundation or registered seed costs more than common

A certified field of Coronado sideoats grama near Dunnigan, California. This field is completely weed free; uniform water application insures uniform growth and maturity. 
seed, but this is more than compensated for by the assurance of pure seed which is free of weeds and mixtures of other types or strains.

\section{When to plant}

Perennial, cool-season grasses germinate and emerge rather quickly when soils are warm. Planting in the early fall (preferably September) and irrigating the stand up ensures larger and more productive plants the following spring. Such stands can often produce an appreciable amount of seed in the first crop year. Winter or spring seeding will produce little or no seed the first year, requiring that the stand be carried through the following winter before seed can be produced.

In areas subject to severe frosts, seeding should be done early enough in the fall to ensure sizable plants before the onset of winter weather, or the grower may have to depend on late spring seeding.

Warm-season grasses should be seeded in the spring. Most will produce seed in the same year of seeding. Seeding just before the normal planting time for sudangrass is usually safe. In some areas of southern California it may be possible for warm-season grasses to be seeded before early fall, thereby producing a heavier seed crop the following year.

\section{Seeding}

With few exceptions, the largest yields are obtained by seeding in rows. This allows the grower to cultivate for early weed control, and later, hand-weeding and roguing. In addition, equipment can move freely in the field for insect and disease control and fertilizer applications. Irrigation furrows between rows help assure more even distribution of water.

Row widths vary from 20 to 36 inches, depending on the growth characteristics of the grasses and the wheel spacings of the agricultural equipment. Short grasses, such as crested wheatgrass, bentgrasses, red fescue, and bluegrass, will generally produce more seed from narrower row spacings. Tall grasses, such as intermediate and tall wheatgrass, orchardgrass, and switchgrass require wider row spacings.

Seeds of the various grass species differ in size from very small, such as the lovegrasses, to much larger, such as the bromegrasses. To ensure rapid and maximum seedling emergence and a uniform stand, the depth of seeding must be carefully controlled. Depth bands attached to double-disc furrow openers, or any other positive depth regulator, are satisfactory. Shoe-type openers, as used on sugar beet and vegetable seed planters, can also be used.

If the stand is expected to be irrigated up in well-prepared, level seedbeds, very shallow seeding gives the best results. The small seeds, such as lovegrass, bluegrass, bents, etc., should be placed no deeper than one-fourth of an inch; larger seeds, depending on size, should not be placed deeper than one-half inch.

Use low seeding rates to prevent excessive crowding in the row. The seeder should be able to deliver a uniform flow of seed at low rates. Poor seed distribution can cause long skips in the row.

Nearly all types of seeders give good results if used properly. Ordinary grass seeders and fluted-feed grain drills will handle most grass seeds when all drill runs, except those necessary for the desired row spacing, are covered. Multiplerow bean and beet planters, with flutedfeed type cans instead of the knock-out plate type feed, have proved very successful. Planet Jr. seeder units are used quite successfully, but they work best for free-flowing seeds.

The table on page 8 lists suggested seeding rates. These are based on seed of high purity and germination. A substandard seedbed, or adverse conditions would usually require higher rates. 


\section{Don't compromise with weeds}

A good grass seed producer never allows weeds to mature in a seed field. It is more economical to remove the weeds in the field than from the harvested seed. Start with a clean field and keep the weeds under control. Slowgrowing, seedling-grass stands can be smothered out by fast-growing weeds.

Cultivation is the key to weed control, but cultivate only when weed control requires it. Cultivation should be discontinued when the crop is tall enough to be injured by machinery moving through the field.

Cultivations may be supplemented by cautious use of chemical sprays. The aerial portions of many grasses are tolerant or resistant to 2,4-D, but the roots may be very susceptible. As a precaution, 2,4-D should not be applied to a seedling-grass stand just before a rain or an irrigation. An entire stand of healthy hardinggrass seedlings was killed when a very light rain just after spraying washed the 2,4-D down into the root zone.

2,4-D and selective dinitro sprays can be used to eliminate broadleaved weeds. However, no present chemical herbicide can be recommended for selective control of contaminating grass weeds. These must be controlled by cultivation.

Before sprays are used, grass plants should be at least 2 to 3 inches high or past the third- to fourth-leaf stage. There has been no apparent damage to grass plants when 2,4-D has been applied at rates of three-quarter to one pound acid equivalent per acre.

Manufacturer's recommendations as to amounts of 2,4-D and dinitro selectives to apply per acre should be followed. The proper precautions should be taken at all times in using weed sprays. It is advisable to observe the effect of a spray

Seeds in these photos and the ones on pages 2 and 3 are approximately actual size.
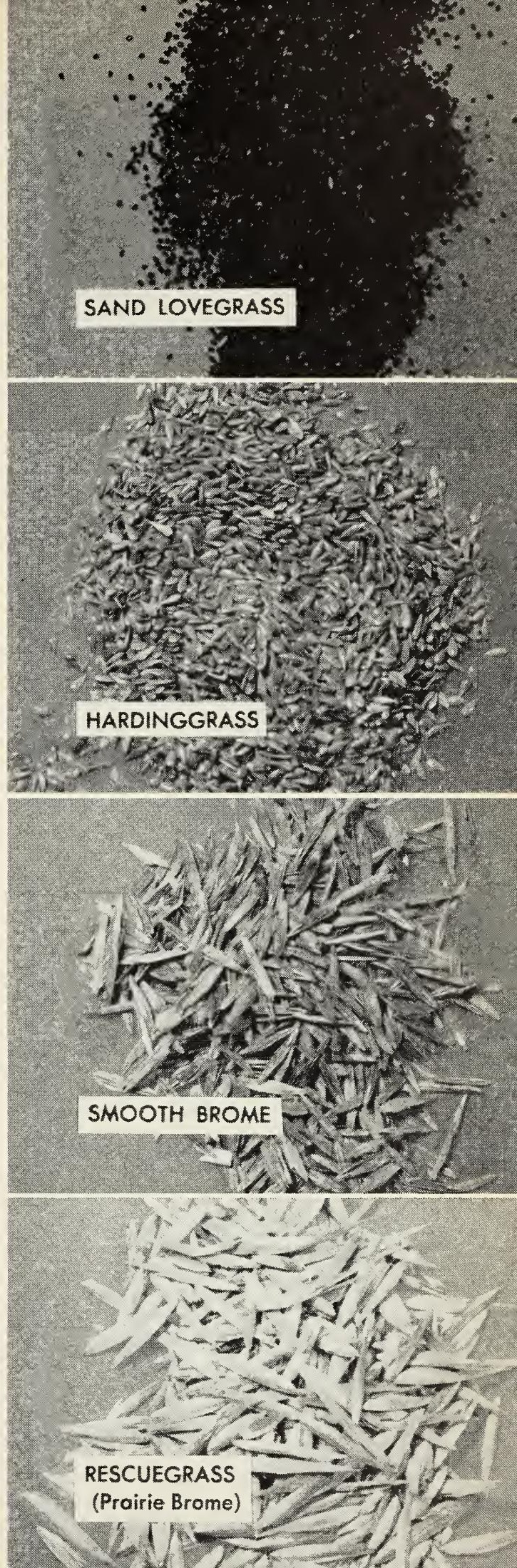
on a small section of row before applying it to the entire field.

\section{Insects and diseases}

It is not possible to discuss here all the diseases and insects that may attack or become a problem on all grasses. Cut worms, thrips, red spiders, and aphids are perhaps the more important insects that may be troublesome. Mildew, rust, and smut are among the diseases known to attack some grass seed crops in California.

\section{Soil fertility}

It is impossible to make definite fertilization recommendations for all California conditions. Known soil deficiencies should be corrected. Most grasses respond in seed yield and vegetative growth to rather high rates of nitrogen. It should be remembered, however, that response to fertilizers varies greatly with soil and previous cropping history. Each grower must determine his exact needs by field tests and experience in his area.

A seedling stand will benefit by an application of 20 to 30 pounds of nitrogen broadcast, or banded below the drill row at seeding. Phosphorus and potash may also be added to help stimulate early and rapid root development. Banding the fertilizer is preferred where weeds may be serious.

Grasses vary widely in the amount of nitrogen they can profitably use in producing a high-yielding seed crop. Some, such as bluegrass, switchgrass, and blue panic, can benefit from applications of 150 to 250 pounds or more of nitrogen per acre. Others, such as the sideoats gramas, will use about 50 pounds per acre per seed crop. Until more specific information is obtained for each, it is felt that, as a general rule, the cool-season grasses will benefit more, as a seed crop, when new growth is encouraged in early fall. About one-third of the total nitrogen should be applied by the first of September, another third by the last of October, and the remainder in early spring when the plants resume growth. Fertilizer applications for warm-season grasses should start just before resumption of new growth in the spring. Two or more applications should be spaced to provide ample nitrogen through the growing season for each seed crop. The last applications should be the lightest.

\section{Irrigation}

The root systems of many perennial grasses penetrate the soil to depths of five feet or more. However, the maximum effective working depth of this root system is perhaps less than two and onehalf feet. The first two feet of soil contain the bulk of the root system that supports the rather large volume of vegetative growth accumulated in producing a seed crop. The frequency and amount of water applied to keep this soil volume above the wilting point will depend in part on the water-holding capacity of the soil.

Yields are highest and seed heaviest if seed fields are never allowed to become stressed for lack of soil moisture. Irrigations should continue as close to harvest as possible.

After harvest the irrigation schedule can be lengthened. Water is applied only when necessary to keep the stand alive until time to resume vigorous growth for the next season's crop.

YOUR BEST SOURCE OF LOCAL INFORMATION on the growing of grass seed is your University of California Farm Advisor Office. The services of these trained agricultural experts are yours for the asking. 


\section{HARVESTING . . .}

\section{is an extremely critical operation \\ as to timing and machine efficiency}

\section{When to harvest}

The actual date of harvest is determined by careful observation of the maturing stand. As grasses mature, the seed goes through the stages of : 1) milky, 2) soft dough, 3) medium dough, 4) hard dough.

The crop should not be harvested until the majority of the maturing heads throughout the field are entering the hard dough stage-usually about the time the top seeds in the head have just started to shatter. This can be determined by gently tapping the grass head in the palm of the hand.

If the crop is harvested much before the hard-dough stage, a large percentage of the seeds will be light and shriveled, and of low viability. It is imperative that all harvesting equipment be ready for use at least one week before the expected date harvesting is to begin. Under hot, dry conditions the change from medium. to hard-dough can be very rapid. A few days during this critical period can carry the crop past the best harvesting stage and result in excessive seed shatter.

\section{Harvesting methods}

Binding. Under most California conditions, binding the crop for delivery to a central curing and threshing area is costly in equipment and labor, and results in excessive seed losses in the field.

The cutter bar of the binder should have lifter-type guards mounted to run along each side of the grass rows. Some guards are extended with snub-nosed shoes.

Modification of the binder to save shattered seeds can result in saving as much as 10 per cent of the seed crop. The grain wheel end of the horizontal binder platform is extended out, up, and around the outside platform draper roll to prevent shattered seed from being carried out and onto the ground. Sheet metal is fastened over the "bull wheel," extend. ing down beneath the elevator draper on

Sand lovegrass (left) has open, feathery panicles with small flowers. Care is needed in threshing to prevent seed being blown out of the back of the machine with the straw. The great volume of plant material in switchgrass (right) makes it necessary to thresh at a low acre-per-hour rate to prevent overloading the machine and losing excessive amounts of seed.

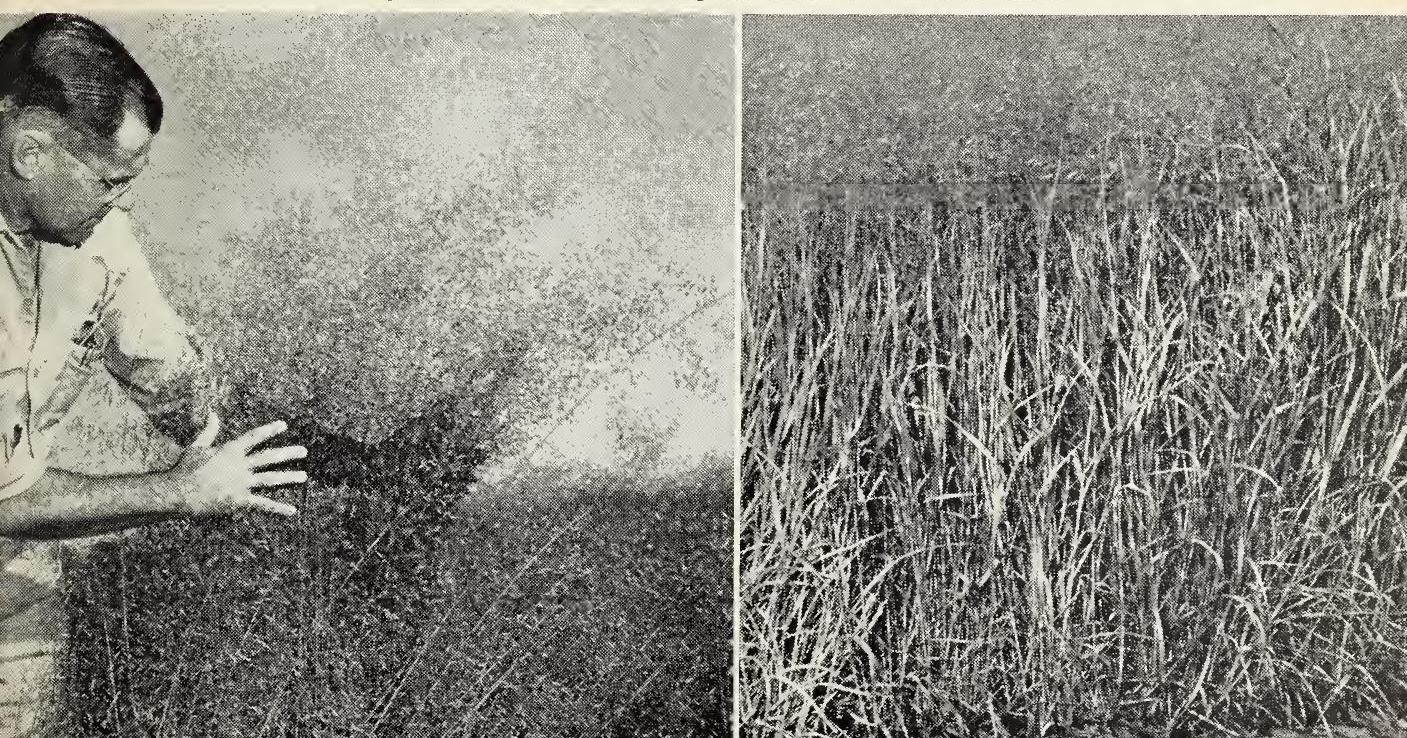




\begin{tabular}{|c|c|c|c|}
\hline \multirow{2}{*}{ Species } & \multirow{2}{*}{$\begin{array}{l}\text { Approximate no. seeds } \\
\text { per pound } \\
\text { (pure seed) }\end{array}$} & \multicolumn{2}{|c|}{$\begin{array}{l}\text { Suggested cylinder speed and } \\
\text { concave clearance settings }\end{array}$} \\
\hline & & $\begin{array}{l}\text { Cylinder } \\
\text { speed }\end{array}$ & $\begin{array}{c}\text { Concave } \\
\text { clearance }\end{array}$ \\
\hline & & rpm & inches \\
\hline Bentgrass. & $7,000,000-8,000,000$ & $5,900-8,000 \mathrm{fpm}^{\mathrm{b}}$ & $1 / 16-3 / 32$ \\
\hline Smoothbrome . . . . . . . . . . & $170,000-200,000$ & 1,000 & $3 / 8$ \\
\hline Tall fescue..... & 225,000 & 1,000 & $1 / 4$ \\
\hline Red and chewings fescue ..... & 565,000 & 1,000 & $1 / 4$ \\
\hline Sideoats grama .......... & 125,000 Clusters & $1,200-1,600$ & $3 / 8$ \\
\hline Hardinggrass. . & 350,000 & $900-1,300$ & $3 / 8$ \\
\hline Lovegrass . . . . . . . . . . . & $1,300,000$ & 1,500 & $1 / 8$ \\
\hline Tall oatgrass . . . . . . . . . . & 130,000 & 1,000 & $1 / 4$ \\
\hline Orchardgrass. & 650,000 & $1,000-1,300$ & $1 / 8$ \\
\hline Switchgrass. & $80,000-100,000$ & 1,500 & $1 / 4$ \\
\hline Blue panic. . & 650,000 & 1,500 & $1 / 4$ \\
\hline Rescuegrass & 68,000 & 1,400 & $3 / 8$ \\
\hline Rhodesgrass. & $1,700,000$ & $1,100-1,400$ & $1 / 8$ \\
\hline Timothy.... & $1,319,000$ & 1,400 & $1 / 8$ \\
\hline Bluegrass. . & $2,200,000$ & $5,900-8,500 \mathrm{fpm}^{b}$ & $1 / 16-3 / 32$ \\
\hline Crested wheatgrass. & $165,000-200,000$ & 1,400 & $1 / 4-3 / 8$ \\
\hline Intermediate wheatgrass & 88,000 & 1,300 & $1 / 4-3 / 8$ \\
\hline Tall wheatgrass....... & 79,000 & 1,500 & $1 / 4-3 / 8$ \\
\hline
\end{tabular}

a These should be used as a starting point, and adjustments made to suit conditions.

b "rpm" is not a satisfactory method of expressing cylinder speeds. Threshing action is dependent on the peripheral speed of the outside edge of a cylinder bar or the tip of a spike tooth on the cylinder. This depends on the diameter of the cylinder. Since diameters vary with make and model of combines and threshers, feet per minute is a more accurate measurement.

Use the following equation to find the cylinder speed in revolutions per minute (rpm) for any given cylinder diameter and cylinder peripheral speed in feet per minute (fpm).

$$
\text { Cylinder rpm }=\frac{\text { cylinder peripheral speed }(\mathrm{fpm})}{3.14 \times \text { cylinder diameter in feet }}
$$

run on all the grasses mentioned. So far, however, the most practical method of harvesting has been windrowing the crop with a center-delivery, self-propelled swather. When the crop has cured it can be threshed from the windrow by a selfpropelled combine equipped with a pickup attachment.

Windrowing must be done at night or when the plants are damp with dew and less subject to shatter. For the cutter bar to operate satisfactorily in the short, straw-heavy growth, the forward speed of the windrower should be quite slow -about 1 to $1.5 \mathrm{mph}$. Higher speeds will result in incomplete cutting. A correctly positioned fix-bat-type reel driven 20 to 30 per cent over ground speed will keep the cut material moving away from the cutter bar and shatter a minimum of seed.

Threshing with a self-propelled combine can usually start three to five days after windrowing, depending on crop and weather conditions. The forward speed must be slow $(0.5$ to 1.0 acre per hour) to prevent overloading the machine. The peripheral speed of the pickup attachment should be no more than 10 to 15 per cent greater than the combine ground speed.

Threshing. Threshing grass seed is usually not difficult if adjustments are made to accommodate the characteristics of the crop being harvested. Here are a 
few important suggestions often overlooked by some growers.

A pan carried under the body of a harvester can save the seed that leaks out of the auger housings, elevators, and between the walls and moving parts.

Most grass seeds do not readily separate from the straw. The machine must be fed slowly enough to handle the straw without carrying good seed out of the machine with the straw.

Because most grass seeds are very light, very little air can be used on the shoe sieves. It is often necessary to remove some of the fan blades, block off the air intake, or disconnect the fan entirely, to sufficiently reduce the air velocity in the shoe.

Each grass species requires a different adjustment of cylinder speed and concaves, sieve opening or types of sieve, and air control to prevent injury and excessive loss of seed. Adjustments will also vary with daily and seasonal con- ditions. The best adjustments for any particular grass are learned only through experience.

Excessive loss of threshed seed in the straw and over the shoe usually indicates that too much material is being fed into the machine. Excessive loss of threshed seed over the shoe can also result from too much air or insufficient opening of the top sieve. Unthreshed seed loss is usually associated with insufficient cylinder speed, cylinder-concave clearance, or too few teeth in the concaves. Broken seed in the grain tank is nearly always the result of excessive cylinder speeds.

Limit the operation to threshing. Cleaning can best be done in the seed cleaning plant with machines made specifically for that purpose.

The regular checking of the straw carrier and shoe sieves for blockages is necessary for a good threshing job. 
The growers most successful in producing consistently high grass seed yields are those who recognize the value of these recommendations:

1. Use the best and most productive soil available. Soils unsuited for other crops are not likely to produce maximum grass seed yields.

2. Well graded and leveled land permits uniform water application that is necessary for uniform maturity of the field. Dry or wet areas within a field speed and delay maturity respectively, reducing yield average.

3. Careful attention must be given to seedbed preparation and seeding. An even, vigorous, uniform stand competes well with weeds; blank spaces or thin spots invite weeds. A uniform stand promotes uniform seed maturity.

4. Establish clean, weed-free stands. Each operation to remove weed seeds in seed cleaning also removes crop seeds. The more difficult the cleaning problem, the more good seed is lost.

5. For maximum yields, water and fertilizer applications must be adequate and timely.

6. Crop damage by disease, insects, or rodents must be recognized and checked early.

7. Adjust general recommendations as required by local conditions of soil and climate.

8. Choose the method of harvest best suited to individual needs or circumstances. Some methods are usually more economical than others. Regardless of the method used, careful attention to proper operation is necessary to get the seed produced into the grain tank or sack. A great part of the profit from grass seed production can often be found on the ground after harvest. 


\section{AGRONOMY TRAINING}

leads to many careers

\section{AGRICULTURAL INDUSTRIES RESEARCH ORGANIZATIONS GOVERNMENT AGENCIES FARMING}

Agronomy deals with the production and improvement of field crops, pastures, and rangelands.

Agronomic crops are grown on more than half of California's agricultural land.

Trained agronomists are needed to

produce more foodstuffs.

handle speciality crops.

develop improved varieties.

devise and apply scientific methods.

Training at Davis has special advantages: Instructors who are leaders in their fields, and are active in research on today's farm problems.

The University farm, for practice and experiment in one of the nation's richest farm areas.

Modern facilities, for better study and research.

An uncrowded campus, with many new buildings.

Letters and Science college on the same campus, broadening the scope of education.

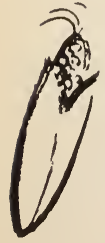

on agronomy write to Maurice L. Peterson, opportunities chairman, agronomy department.

on entrance write to Howard B. Shontz, requirements office of the registrar.

on college see your County Farm Ad. opportunities visor for college entrance counsel.

\section{University of California - Davis, Calif.}

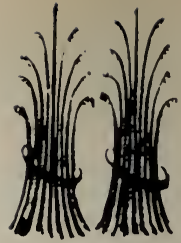

CAREERS IN

farm management

farm operation

seed processing

seed marketing

agricultural industry

farm supply houses

farm service houses

teaching

research

Agricultural Extension

Service

crop improvement

associations

departments of agriculture

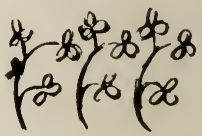

STUDY INCLUDES

management

adaptation

plant breeding

culture

utilization

processing of cereals

oil crops

cotton

sugar beets

beans

hay crops

range plants

irrigated pastures

distribution

variety improvement

soil management

weed control

crop diseases

animal husbandry

agricultural machinery 